\section{Growing with experience}

The generation of memory $\mathrm{CD}^{+}$ T cells following exposure to a pathogen or vaccine is required for protection against subsequent infections by the same pathogen. It has long been thought that the maximum size of the memory $\mathrm{CD}^{+} \mathrm{T}$-cell compartment is fixed and, consequently, that the generation of memory $\mathrm{CD}^{+}$ $T$ cells of new specificities must necessarily reduce the number of pre-existing memory $\mathrm{CD}^{+} \mathrm{T}$ cells. However, new research published in Nature shows that the size of the



memory $\mathrm{CD}^{+} \mathrm{T}$-cell compartment increases following immunization and that the generation of new memory CD8 ${ }^{+} \mathrm{T}$ cells does not significantly affect the number of pre-existing memory $\mathrm{CD}^{+} \mathrm{T}$ cells.

To examine how the generation of new memory CD8 ${ }^{+} \mathrm{T}$ cells affects the pre-existing population, the authors first transferred naive $\mathrm{CD}^{+} \mathrm{T}$ cells that were specific for an immunodominant epitope of lymphocytic choriomeningitis virus (P14 cells) to naive mice and then infected the mice with the virus. Once the easily detectable population of pre-existing memory $\mathrm{CD}^{+} \mathrm{T}$ cells had been generated, the mice were given three heterologous primeboost immunizations to induce the generation of new memory $\mathrm{CD}^{+}$ $\mathrm{T}$ cells that were specific for the $\mathrm{N}$ peptide of vesicular stomatitis virus. The generation of the new memory population resulted in a reduction in the percentage of the pre-existing P14 cells, consistent with previous studies. However, the proportion of memory CD8 ${ }^{+} \mathrm{T}$ cells in the blood was permanently increased following the prime-boost immunizations (measured 94 days after the final immunization), suggesting that the size of the memory CD8 ${ }^{+} \mathrm{T}$-cell compartment is flexible.

Further analysis showed that following the prime-boost regimen, the number of effector memory $\mathrm{CD}^{+} \mathrm{T}$ cells $\left(\mathrm{CD} 44^{\text {hi }} \mathrm{CD} 62 \mathrm{~L}^{\text {low }}\right)$, but not naive $\mathrm{CD}^{+} \mathrm{T}$ cells, $\mathrm{CD} 4^{+} \mathrm{T}$ cells or B cells, was dramatically increased in the spleen, liver, bone marrow and lungs, but not in the lymph nodes. In addition, the number of memory N-peptide-specific CD8 ${ }^{+}$ $\mathrm{T}$ cells that developed in these mice was equivalent to the total number of memory CD8 ${ }^{+} \mathrm{T}$ cells in control mice that had received saline instead of the prime-boost immunizations. Interestingly, the actual number of pre-existing memory $\mathrm{CD}^{+} \mathrm{T}$ cells (that is, P14 cells) was only modestly reduced in the prime-boosted mice, indicating that the generation of a large number of new memory $\mathrm{CD}^{+}$ $\mathrm{T}$ cells results in a smaller loss of preexisting memory $\mathrm{CD}^{+} \mathrm{T}$ cells than was previously predicted, based on analyses of cell percentages.

So, this study shows that the size and proportion of the effector memory CD8 ${ }^{+} \mathrm{T}$-cell compartment outside of the lymph nodes is not fixed, but that it can adapt to immunological experiences. In addition, pre-existing immunity to other pathogens is not significantly ablated by the generation of large numbers of new memory CD8 ${ }^{+} \mathrm{T}$ cells. These findings could be exploited for vaccination, especially for protection against pathogens that require a high frequency of $\mathrm{CD}^{+} \mathrm{T}$ cells.

Olive Leavy

ORIGINAL RESEARCH PAPER Vezys, V. et al. Memory CD8 T-cell compartment grows in size with immunological experience. Nature $13 \mathrm{Nov}$ 2008 (doi:10.1038/nature07486) 